\title{
Role of Exploratory Factor Analysis Applicability of TQM Practices on the Items of Quality Culture in the Kingdom of Saudi Arabia
}

\author{
Faihan Mosaad Saud Al-Otaibi ${ }^{1}$ \\ ${ }^{1}$ College of Business, University Utara University Malaysia, 06010 UUM, Kedah, Malaysia \\ Correspondence: Faihan Mosaad Saud Al-Otaibi, College of Business, University Utara University Malaysia, \\ 06010 UUM, Kedah, Malaysia. E-mail: ft4s@hotmail.com
}

Received: August 19, 2014

Accepted: November 17, 2014

Online Published: December 20, 2014

doi:10.5539/ijbm.v10n1p136

URL: http://dx.doi.org/10.5539/ijbm.v10n1p136

\begin{abstract}
This study aims to investigate the relationship between Total Quality Management (TQM) practices and quality culture in Kingdom of Saudi Arabia. The samples comprised 388 samples and data was collected through a questionnaire from the managers of leading construction companies in the Kingdom of Saudi Arabia. The respondents were requested to answer self-administered questionnaires, and send their feedback to the researcher, where 5 points rating scale was used to elaborate on varying responses. Additionally, this study employed multiple regression analysis in order to test the relationship between independent variables (TQM practices namely, education and training, customers focus, information and analysis, continuous improvement, process management and top management commitment) and dependent variable (quality culture). The results of this study revealed a positive relationship between education and training and quality culture. In the same path, the results revealed a positive association between customer focus and quality culture and a positive association between information and analysis and quality culture. Additionally, the results also revealed a positive relationship between continuous improvement and quality culture and a positive relationship between process management and quality culture. Finally, the study results showed a positive top management commitment-quality culture relationship. The study provided recommendations and directions for future research.
\end{abstract}

Keywords: total quality management, quality culture, Saudi Arabian construction

\section{Introduction}

Quality culture is referred to as an environment reflecting positive commitment to quality outcomes, products, systems, and processes; it stresses upon continuous improvement. This is intertwined with the organization's policy or mission statement and is described as a way of making decisions. It is generally referred to as an attitude and values about improving the quality level of service. It is used to enhance customer relationship, employee communication and employee attitude. The ideal way to develop a sustainable quality culture is by offering regular training and educational sessions.

In this regard, Hart (1994) claimed that in the context of the construction industry, quality has three dimensions, which are, getting the job done in a timely fashion, ensuring that the fundamental features of the final scheme are aligned with the obligatory stipulations, and receiving the job done within the financial plan. Every quality construction project should cover the above three dimensions. Construction quality is primarily related with adherence to stipulations and the appropriateness for use. Added to this, quality in such industry is often described as meeting the requirements of the relevant individuals namely the designer, the constructor, the regulatory bodies and the owner (Ferguson \& Clayton, 1988).

Construction companies consider the ISO 9000 certification as the way to develop a reputation characterized by quality assurance in the engineering and construction project management (Bubshait \& Al-Atig, 1999). In addition, majority of the companies have often utilized ISO certification as a marketing tool.

Dynamic competition in the local and global levels leads to greater levels of quality in almost every business activity and sector and to ensure this competitiveness in the developing global market, construction firms in different countries attempt to meet internationally acknowledged quality standards in terms of TQM (ISO 9001 and quality standard) and criteria of quality awards. However, there are variations in the level of TQM 
implementation in diverse countries. Literature presents that TQM is now considered a common accepted practice through the acceptance of both frameworks (Wilson \& Collier, 2000). Some of the famous companies that adopted TQM are Morrison Construction Group (Sommerville \& Sulaiman, 1997), and Takenaka Corporation (Jido, 1996; Fung \& Wong, 1995). In the context of construction companies, better performance in the form of higher consumer happiness, better project quality and higher market share have been reported by many companies adopting such practice (Wong \& Fung, 1999).

In the context of Saud construction firms, their awareness of globalization and maintenance of their competitive advantage, have urged them to implement TQM strategies. In fact, Saudi Arabia is deemed to be the leading Middle Eastern country in terms of GDP, ranked $12^{\text {th }}$ in the world, and measuring an area approximately 2.2 million square km. (Jasimuddin, 2001). Saudi Arabia is a significant net creditor to the other countries around the globe with almost no foreign debt. Added to this, Saudi Arabia is also one of the advocates of free trade based on honest competition (Jasimuddin, 2001).

In the last decade, the Saudi Arabian construction industry has witnessed phenomenal growth only to be stunted by the 2008-2009 recession. Nevertheless, the current global economic recession has led to the minimal demand for infrastructure projects worldwide but in Saudi Arabia, the government has been investing in increasing infrastructure projects that occupy the country's construction companies (Saudi Report, 2012). The Saudi government has reportedly invested \$22 billion on several infrastructure projects to keep the economy alive even during the recession. As a consequence, it is estimated that the construction industry will grow at $5.2-5.4 \%$ for the period 2012-2013 (Saudi Report, 2012).

The remaining part of the paper is organized in the following way; in section 2, the related works are presented and this is followed by section 3 where the data collection methodologies are discussed. Section 4 and 5 contains the data analysis, main findings and conclusion. The primary aim of this study is to statistically explore factor analysis on the quality culture items based on TQM among Saudi construction firms.

\section{Literature Review Hypotheses Development}

\subsection{Education and Training and Quality Culture}

The significance of training and development was stressed by Ahire et al. (1996) when he stated that worker empowerment and participation framework will be useless until and unless workers receive official, systematic training in quality management. This contention was first brought to light by Ishikawa (1985) who claimed that quality begins and ends with training. Similarly, McAdam and Kelly (2002) supported the claim by confirming that training and development are important elements in TQM activities. Moreover, Zhang et al. (2000) demonstrated that firms believe that education and training form a significant part of all TQM initiatives.

According to Crosby (1996), training and development of employees and continuous improvement result in satisfaction of customers' needs. He further noted that organizations should create environment that lets employees work towards quality production and delivery before satisfying external customers. In other words, it is almost impossible to meet and surpass the expectations of the outdoor consumers in cases when delivery of quality is not carried out well by the employees. Hence, each and every employee in the firm should be provided the required training and education for their tasks. This is contrary to the traditional notion that employee training and development is unnecessary as they are costly. In reality, the belief today is that training and development is the fulcrum that helps in TQM process implementation. Also, several TQM organizations consider employee education and training as a stepping stone to improving customers' value and the key to the successful running of the organization. On the basis of the previous discussion and supporting arguments, the following hypothesis is developed;

\section{H1: There is a relationship between education and training and quality culture.}

\subsection{Customer Focus and Quality Culture}

Customers are generally considered as an economical asset despite the fact that they are not included in the balance sheet (Fornell, 1994, cited in Kanji et al., 2000). In this regard, Deming recommends overhauling the current management methods in order to achieve a culture that brings about constant enhancement for customer satisfaction. This is aligned with TQMs advocacy towards efforts focused on consumer satisfaction in a right first time and all time method.

Customer satisfaction is the driver of successful quality management effort according to several TQM gurus (e.g. Crosby, 1989; Deming, 1986; Kanji, 1998; Oakland, 2000; Rao et al., 1996; \& Spring et al., 1998). To this end, successful consumer retention and market breakthrough lies in the idea and realization of consumer satisfaction 
(Rao et al., 1996). Along a similar contention, Zairi (1994) stated that customer satisfaction measurement is the basis of TQM principles.

TQM brings about significant organizational changes with customer satisfaction at its core, providing the organization with the requisite competitive advantage (Bagchi, 1997). Four important TQM characteristics were identified by Bagchi (1997) as the basis of customer satisfaction; they are top management's direct involvement, customer-orientation, company-wide participation, and the utilization of systematic resolution methods to resolve issues of quality. Owing to the fact that customer satisfaction is the core to any business objective, all other activities that go against it or that do not add to it should be removed. This guarantees the absence of waste in the processes employed and where there is absence of waste, prices do not require to be increased to cover the costs of wastes and the maintenance of costs provides the organization with the competitive advantage needed. Armed with this argument, Bagchi develops the relationship between TQM and competitive advantage.

According to Lee and Roberts (1997), customer-oriented approach to TQM is based on a western philosophy and they claimed that the current TQM philosophies and practices are dehumanizing owing to its vested interest in the organization and the owners. Instead, they recommended that TQM approaches should personify the concepts of wisdom originating from the cultures of the nations and the instances of Confucianism that stress on learning and self-cultivation. They further proposed that it would be best to combine the above principles with 'western quality guru' principles to lead to the development of a Global Total Quality Management Strategy (GTQMS) that will assist businesses in the identification of their strengths and weaknesses in the improvement of their priorities. Based on the theoretical perspective and debate above, the following hypothesis is expressed:

\section{H2: There is a relationship between customer focus and quality culture.}

\subsection{Information and Analysis and Quality Culture}

Information and analysis involves the various policies and strategies, quality audit, quality costs, department/function performance, employee-supplier performance among other activities in terms of their evaluation. In case of inferior dissemination of produced information, quality methods like benchmarking and statistical process control (SPC) tools will be useless and in order to maintain customer focus, a timely feedback of customer survey outcome should be ensured by the organization in order to distribute it to other areas of the organization (Metri, 2005).

Several studies, have examined quality information and performance. Even quality awards such as the Malcolm Baldrige National Quality Award (MBNQA) advocates the significance of quality information by stating that it forms the core of a TQM initiative. Such an award deems information and analysis to be significant for effective management and for a fact-based system for competitiveness enhancement (Robert, 2001). On the basis of the above discussion, the hypothesis is formulated as follows:

\section{H3: There is a relationship between information and analysis and quality culture.}

\subsection{Continuous Improvement and Quality Culture}

The implementation of continuous improvement in daily activities management is crucial for the employees working towards realizing the organizational objectives. In this regard, Anderson et al. (1994) claimed that continuous improvement is based on the process management principles that generate increased improvement and product, service and process innovation. Continuous improvement entails the systematic measurement and focus on product/service, productive teams, cross-functional process management, and the achievement, sustenance and enhancement of standards. Because of the dynamic global competition that is solely based on customer demand, changes are continuously taking place as to what constitutes acceptable standards. The best products and services currently on demand may become obsolete tomorrow due to the increasing customer expectations brought about by the global environment changes. As a consequence to these changes, organizations are benchmarking processes from their rivals to uncover the secrets behind successes.

To this end, Quirke (1995) contended that the primary challenge faced by organizations is how to obtain customers, retain them, develop relationships with them, and find ways to bring them value for money before another competitor does. This can be achieved through a continuous improvement of products, services, processes and people. Such improvement brings about refinement and improvement to services, products and systems in order to provide enhanced value to customers (Stahl, 1995). Based on above discussion, the hypothesis is formulated as follows:

H4: There is a relationship between continuous improvement and quality culture. 


\subsection{Process Management and Quality Culture}

Activities within the organization can be referred to as processes and thus, if the TQM initiative attempts to achieve overall quality performance, then process management becomes a must. Its focus is on adherence to quality and it ensures that process capability is able to bring about the production needs (Zhang et al., 2000). Similarly, Oakland (1993) revealed that process management is a process of convincing employees that they are responsible for their work in terms of customer satisfaction and Motwani (2001) contended that process management adds value to a process, maximizes each employee's productivity and enhances the quality of the firm. According to McAdam (1996), process management (process-based approach) leads to an enhanced customer satisfaction and eradicates issues linked with management by using the functional based approach. Based on above discussion, the hypothesis is formulated as follows:

\section{H5: There is a relationship between process management and quality culture.}

\subsection{Top Management Commitment and Quality Culture}

To management commitment or leadership is the top important element in TQM implementation (Kanapathy, 2008). In addition to this, several scholars have demonstrated that leadership does not only act as a related issue in quality culture but also a crucial tool in performance improvement (Kotter \& Heskett, 1992; Saraph et al., 1989).

Top management commitment was also established to be lacking and as mentioned earlier, this plays a crucial role as it brings about the change in power relationships, systems modifications, and reallocation of resources. Added to this, many authors stressed top management commitment's significance in TQM implementation and adoption of a research-based method (Steele, 1993). Based on above discussion, the hypothesis is formulated as following:

\section{H6: There is a relationship between top management commitment and quality culture.}

\section{Research Method and the Study Models}

This study is an attempt to examine the factor of TQM practice and quality culture in Kingdom of Saudi Arabia among 388 samples. In order to achieve this objective, this study investigated the role of factors analysis applicability in quality culture, and data was gathered through distribution of structured questionnaires among project managers of selected areas of Saudi Arabia. In certain cases, the questionnaires were returned through e-mail after reminders by phone, after which the researcher reviewed the answers and differences were not found.

In sum, the relationship between factor of TQM practice and quality culture was studied by using the following model:

$$
Q C=\alpha 0+\beta 1 * E A N+\beta 2 * C F+\beta 3 * I A A+\beta 4 * C A I+\beta 5 * P M+\beta 6 * T M C+\varepsilon
$$

Table 1. Quality management practices dimensions and number of items

\begin{tabular}{lll}
\hline \multicolumn{1}{c}{ VARIABLES } & ACRONYM & No. of items \\
\hline Dependent Variables (DV) & & \\
\hline Quality Culture Dimensions & QC & 25 \\
\hline Independent Variables (IVs) & & \\
\hline Education and Training & EAT & 4 \\
Customers Focus & CF & 4 \\
Information and Analysis & IAA & 4 \\
Continuous and Improvement & CAI & 3 \\
Process Management & PM & 4 \\
Top Management Commitment & TMC & 4 \\
\hline
\end{tabular}

\section{Findings and Data Analysis and Discussion}

The current study carried out exploratory factor analysis on the quality culture comprising five aspects: improvement orientation, team work orientation, mission and goal orientation, management style, and personal influence performance. For improvement orientation six items were used, for team work orientation four items were employed, for mission and goal orientation, five items were employed and for management style four items were considered. Lastly, for personal influence performance six items were considered. 
Table 2. Regression results of model (Dependent $=\mathrm{QC})$

\begin{tabular}{ll}
\hline Variables & Coef \\
\hline Education and training & $\mathbf{P}$ \\
Customers focus & $0.274^{* *}$ \\
Information and analysis & $0.508^{* *}$ \\
Continuous improvement & $0.335^{* *}$ \\
Process management & $0.286^{* *}$ \\
Top management commitment & $0.169^{* *}$ \\
\hline
\end{tabular}

Note. ${ }^{*} \mathrm{p}<.05, * * \mathrm{p}<.01$

In order to investigate the relationship between TQMP factors and quality culture, Pearson correlation coefficient was used. Table 2 shows the result.

The first hypothesis $\left(\mathrm{H}_{1}\right)$ states: There is a relationship between education and training and quality culture. The result illustrated a positive and low relationship between education and training and competitiveness $(r=0.274$, $p<.05)$. Therefore, the hypothesis was accepted. In particular, the importance of education and training was highlighted in the literature as being essential for developing a quality culture because of its potential impact on competitiveness. It should be pointed out that this study upheld the hypothesis of a relationship between education and training with both quality culture and competitiveness, but the correlation albeit positive was to a lesser degree than for most of the other aspects such that its strength was classified as low.

The second hypothesis $\left(\mathrm{H}_{2}\right)$ states: There is a relationship between customer focus and quality culture. The result illustrated a positive and high relationship between customer focus and competitiveness $(r=0.508, p<.05)$. Therefore, the hypothesis was accepted. In this respect, customer focus enjoyed the same significance, as did management of supplier. In addition, top management commitment and education and training were found to significantly affect quality culture but not competitiveness, whereas process management was found to significantly affect competitiveness but not quality culture.

The third hypothesis $\left(\mathrm{H}_{3}\right)$ states: There is a relationship between information \& analysis and quality culture. The result illustrated a positive and low relationship between information and analysis and competitiveness $(r=$ $0.335, p<.01)$. Therefore, the hypothesis was accepted.

The fourth hypothesis $\left(\mathrm{H}_{4}\right)$ states: There is a relationship between continuous improvement and quality culture. The result illustrated a positive and low relationship between continuous improvement and competitiveness $(=$ $0.286, p<.01)$. Therefore, the hypothesis was accepted.

The fifth hypothesis $\left(\mathrm{H}_{5}\right)$ states: There is a relationship between process management and quality culture. The result illustrated a positive and low relationship between process management and competitiveness $(r=0.169, p$ $<.01)$ and thus, the hypothesis was accepted.

Finally, the sixth hypothesis $\left(\mathrm{H}_{6}\right)$ states: There is a relationship between top management commitment and quality culture. The result illustrated a positive and moderate relationship between top management commitment and competitiveness $(r=-0.478, p<.01)$ indicating that the hypothesis was accepted.

\section{Conclusion and Suggestion for Future Researchers}

This study examined the association between the factor of TQM practices and quality culture in the Kingdom of Saudi Arabia. The sample comprised 388 individuals and data was obtained through distributed questionnaire. Moreover, this study used multiple regressions in order to test the relationship between the independent variables and the dependent variable. This study found a positive relationship between education and training and quality culture and a positive association between customers focus and quality culture. Moreover, it also found a positive association between information and analysis and quality culture and a positive relationship between continuous improvement and quality culture. Added to the above results, this study found process management to positively affect quality culture and finally, this study revealed a positive relationship between top management commitment and quality culture.

This study, like previous published studies, has some recommendation for future researchers. First, this study focused on examining the relationship between TQM practices and quality culture in the Kingdom of Saudi Arabia and to this end, future research could consider examining the same in other GCC countries in order to 
enhance and validate the findings. Second, this study investigated directly relationships so future studies could take into account moderating and mediating effects on the direct relationships.

\section{References}

Ahire, S. L., Golhar, D. Y., \& Waller, M. A. (1996). Development and Validation of TQM Implementation Constructs. Decision Sciences, 27(27), 23-56. http://dx.doi.org/10.1111/j.1540-5915.1996.tb00842.x

Anderson, J. C., Rungtusanatham, M., \& Schroeder, R. G. (1994). A Theory of Quality Management Underlying the Deming Management Method. Academy of Management Review, 9(3), 472-509.

Bagchi Tapan, P. (1997). Competitiveness and TQM: Is the Synergy really a Surprise? Portland International Conference on Management of Engineering and Technology. Portland, Oregon, USA, Proceedings.

Bubshait, A. A., \& Al-Atig, T. H. (1999). ISO 9000 Quality standards in Construction. Journal of Management in $\begin{array}{llll}\text { Engineering, } & \text { November/December } & 1999 . & \text { Retrieved }\end{array}$ http://www.rpd-mohesr.com/uploads/custompages/ISO9000-qualit-standards-construction.pdf

Cordsman, A. H. (2000). Saudi Arabia Enters the 21st Century: Economic, Demographic And Social Challenges. Center for Strategic and International Studies, 1800 K Street NW, Washington DC 20006.

Crosby, P. (1989). Let's Talk Quality: 96 Questions That You Always Wanted To Ask Phil Crosby. New York: McGraw-Hill.

Crosby, P. B. (1996). Quality Is Still Free: Making Quality Certain in Uncertain Times. The Art of Making Quality Certain. New York: McGraw-Hill.

Deming, W. E. (1986). Out of the Crisis. Cambridge University Press.

Everitt, B. S., \& Dunn, G. (1983). Advanced methods of data exploration and modelling. London: Heinemann.

Ferguson, H., \& Clayton, L. (1988). Quality in the Constructed Project: A Guideline for Owners. Designers and Constructors, 1. ASCE, New York.

Fung, P., \& Wong, A. (1995). TQM in Construction Industry-Hong Kong Context. Proceedings of the 1st International Conference on ISO 9000 and TQM. De Montfort University.

Hair, J. F., Money, A. H., Samouel, P., \& Page, M. (2006). Research methods for business. Chichester: John Wiley and Sons Ltd.

Hart, D. R. (1994). Quality Handbook for the Architectural, Engineering and Construction Community. Milwaukee, WI, ASQC Quality Press.

Ishikawa, K. (1985). What Is Total Quality Control? The Japanese Way. Englewood Cliffs, NJ: Prentice-Hall Inc.

Jasimuddin, S. M. (2001). Analyzing the Competitive Advantages of Saudi Arabia with Porter's Model. Journal of Business \& Industrial Marketing, 16(1), 59-68. http://dx.doi.org/10.1108/08858620110365007

Jido, J. (1996). Quality Management with TQM in Takenaka Corporation. Proceedings of International Conference on Quality, Yokohama.

Kanapathy, K. (2008). Critical Factors of Quality Management used in Research Questionnaires: A Review of Literature. Sunway Academic Journal, 19-30.

Kanji, G. K. (1998). Measurement of Business Excellence. Total Quality Management, 9(7), 633-643. http://dx.doi.org/10.1080/09544120050135515

Kanji, G. K., \& Wallace, W. (2000). Business Excellence through Customer Satisfaction. Total Quality Management, 11(7), 6-21. http://dx.doi.org/10.1080/0954412988325

Kotter, J. P., \& Heskett, J. L. (1992). Corporate Culture and Performance. New York. NY: The Free Press.

Lee, S. F., \& Roberts, P. (1997). Quality Management Strategy Evaluation Using Quality Function Deployment Methodology under Chinese Culture. IEEE Explore.

Maull, R., Brown, P., \& Cliffe, R. (2001). Organizational culture and quality improvement. International Journal of Operations \& Production Management, 21(3), 302-326. http://dx.doi.org/10.1108/01443570110364614

Mcadam, R. (1996). An Integrated Business Improvement Methodology To Refocus Business Improvement Efforts. Business Process Reengineering \& Management Journal, 2(1), 63-71. http://dx.doi.org/10.1108/14637159610111482 
Mcadam, R., \& Kelly, M. (2002). A Business excellence Approach to Generic Benchmarking in SME's, Benchmarking. An International Journal, 9(1), 7-27.

Metri, B. A. (2005). TQM critical success factors for construction firms. Journal of Contemporary Management, $10(2), 61-72$.

Mohamed, S. S., \& YuanJian, Q. (2008). The Impact of the Organizational Culture on the Implementation of TQM Programs. 2008 ISECS, International Colloquium on Computing, Communication, Control, and Management. http://dx.doi.org/10.1109/CCCM.2008.303

Motwani, J. (2001). Critical Factors and Performance Measures of TQM. The TQM Magazine, 13(4), 292-300. http://dx.doi.org/10.1108/13683040010362300

Oakland, J. (2000). Total Quality Management-Text with Cases (2nd ed.). Butterworth-Heinemann.

Oakland, J. S. (1993). Total Quality Management. Oxford: Butterworth-Heinemann.

Pinner, J. W. (2003). TQM Practices and Organizational Culture: Japanese versus American Perspectives. Regent University.

Quirke, B. (1995). Communicating change. London: McGraw-Hill.

Rad, A. M. M. (2006). The Impact of Organizational Culture on the Successful Implementation of Total Quality Management. The TQM Magazine, 18(6), 606-625. http://dx.doi.org/10.1108/09544780610707101

Rao, A., Carr, L., Dambolena, I., Kopp, R., Martin, J., Rafii, F., \& Schlesinger, P. H. (1996). Total Quality Management: A Cross-Functional Perspective. John Wiley and Sons.

Robert, J. V. (2001). Using the Baldrige criteria for personal quality improvement. Industrial Management \& Data Systems, 101(7), 363-369. http://dx.doi.org/10.1108/EUM0000000005824

Saraph, J. V., Benson, P. G., \& Schroeder, R. G. (1989). An Instrument for Measuring the Critical Factors of $\begin{array}{llll}\text { Quality Management. } & \text { Decision }\end{array}$ http://dx.doi.org/10.1111/j.1540-5915.1989.tb01421.x

Saudi Arabia Infrastructure Report Q1. (2012). Business Monitor International Publisher, 72.

Sommerville, J., \& Sulaiman, N. F. (1997). The Culture for Quality within the UK Construction Industry: Temporal Relatedness and Dominance. Total Quality Management, 8(2\&3), 279-285. http://dx.doi.org/10.1080/09544129710242

Spring, M., Mcquater, R., Swift, K., Dale, B., \& Booker, J. (1998). The Use of Quality Tools and Techniques in Product Introduction: An Assessment Methodology. The TQM Magazine, 10(1), 45-50. http://dx.doi.org/10.1108/09544789810197855

Stahl, J. M. (1995). Management: Total Quality in a Global Environment. Oxford: Blackwell Publishers Ltd.

Steele, J. (1993). Implementing Total Quality Management for Long- and Short-Term Bottom-Line Results. National Productivity Review, 12(3), 425-441. http://dx.doi.org/10.1002/npr.4040120313

Wilson, D. D., \& Collier, D. A. (2000). An empirical investigation of the Malcolm Baldrige National Quality Award causal model. Decision 36iences, 31(2), 383. http://dx.doi.org/10.1111/j.1540-5915.2000.tb01627.x

Wong, A., \& Fung, P. (1999). Total Quality Management in the Construction Industry in Hong Kong: A Supply Chain Management Perspective. Total Quality Management, 10(2), 199-208. http://dx.doi.org/10.1080/0954412997956

Yong, K. T., \& Pheng, L. S. (2008). Organizational Culture and TQM Implementation in Construction Firms in Singapore. Construction Management and Economics, 26, 248. http://dx.doi.org/10.1080/01446190701874397

Zairi, M. (1994). Measuring Performance for Business Results. London: Chapman \& Hall. http://dx.doi.org/10.1007/978-94-011-1302-1

Zhang, Z., Waszink, A., \& Wijngaard, J. (2000). An Instrument for Measuring TQM Implementation for Chinese Manufacturing Companies. International Journal of Quality and Reliability, 17(7), 730-755. http://dx.doi.org/10.1108/02656710010315247 


\section{Copyrights}

Copyright for this article is retained by the author(s), with first publication rights granted to the journal.

This is an open-access article distributed under the terms and conditions of the Creative Commons Attribution license (http://creativecommons.org/licenses/by/3.0/). 